\title{
A troubling story: Insurance and medical research in Saskatchewan
}

\author{
Harold Merskey DM FRCP \\ Editor-in-Chief, Pain Research \& Management \\ Robert W Teasell MD FRCPC \\ Associate Editor, Pain Research \& Management
}

\begin{abstract}
$\mathrm{T}$ is standard teaching that medicine and health care function in a social setting, and the pain literature is full of material on social and psychological factors. In Pain Research $\mathcal{E}$ Management, we drew attention to the impact of social influences on medical thinking and the readiness with which sections of the medical profession sided with paymasters for insurance companies (1). At that time, we were well aware of the most troubling story in decades in the fields of pain, insurance and medical research $(2,3)$. In her commentary in this issue of Pain Research $\mathbb{E}$ Management, Lorie Terry (pages 101 to 106) provides information about why the scientific commentators have been radically critical of an article by Cassidy et al, published in The New England Journal of Medicine (2), on the basis of both internal evidence and additional information that accrued, some of which was available at the time of the article's publication and some of which subsequently became public.
\end{abstract}

We approached The New England Journal of Medicine with information suggesting that the claims made in the article by Cassidy et al (2) should be reconsidered by the editors. We wanted them to look at additional information, some of which we provided and more of which we offered to provide. This request was made after the publication of the critical letters to which Terry refers and a reply from the authors of the original article. The editors of The New England Journal of Medicine advised us that they thought that the matter had been sufficiently covered in their articles.

We subsequently approached two leading general medical journals in hopes that they would consider our information and that they would entertain a critique of The New England Journal of Medicine article. Both journals refused courteously, partly on the grounds that the original article had not been published in their own journal, and also on the grounds that there was a need for due process in the

Correspondence and reprints: Dr Harold Merskey, 1001 Adelaide Street North, Suite 205, London Ontario N5Y 2M6. Telephone 519-434-8333, fax 519-434-8880, e-mail merskey@on.aibn.com 
form of a reply to our criticisms, which would be difficult to provide in a journal format. One suggestion was to approach the ombudsperson, which we did not think would be effective. After reflection, we concluded that we could not identify any mechanism whereby adequate discussion could then be achieved elsewhere. We considered whether we should seek to have our article published in Pain Research $\mathcal{E}$ Management, with the matter being refereed wholly by another editor and reviewers, to whose identity we would of course be blinded. We decided that because two leading medical journals had been hesitant about publishing this type of material in a peer-reviewed publication, we would not attempt to use a peer-review format in a journal in which we had some influence. Accordingly, we made arrangements with three provincial legal journals to publish the same article, which would then be available to trial lawyers and judges in different parts of Canada, and we hope elsewhere. Thus, at least some of those who would need to face the claims of the Saskatchewan group and the Quebec Task Force would have adequate background knowledge to challenge unreasonable assertions. The three legal journals were The Verdict, the Journal of the Trial Lawyers of British Columbia, The Saskatchewan Advocate and The Litigator, Journal of the Trial Lawyers of Ontario (3).

With the publication of the article by Merskey et al (3) in the legal journals, discussion of these matters in a Canadian medical journal is overdue. We have concluded that it is appropriate to publish the story in these articles as a matter of information and editorial opinion, without claiming peer-review standing.

The article by Terry (pages 101 to 106) presents such information, and also draws attention to another matter that has arisen out of the Saskatchewan experiment, which was conducted by the government that passed the relevant act in 1994 and the insurance company that implemented the act.

Terry, a spokesperson for the Coalition Against No-Fault Insurance and herself a victim - both of an accident and of a deplorable system - gives a brief statement of the background on no-fault insurance in Saskatchewan and a more detailed account of the use of consent that was not free and indeed could be described as coerced - by an insurance company to obtain information that was then provided to a university group. Terry argues, we think correctly, that even if Saskatchewan Government Insurance was entitled to collect extensive information about victims of motor vehicle accidents in Saskatchewan (although the actual act authorizing the present Saskatchewan system does not give them the authority to research the matter), the university group was certainly not eligible to receive such information that was not obtained by means of consent that was entirely free and fully informed.

We think that the fact that claimants were expected to sign a form that heavily emphasized that they could be prosecuted for any false statements, and that their ability to receive payments related to their injuries would be dependent on cooperation with the insurance company, shows that the consent could not be considered to be freely given - It was coerced.

There is also an issue about whether the information obtained was provided on the basis of adequate discussion about what would be done with it. The research hypothesis of the group studying the information could be thought to be favourable to insurers and unhelpful to victims. That is certainly how we interpreted The New England Journal of Medicine paper. If a university group is to undertake such research, we think that it should bend over backwards to ensure that the subjects are aware that the information that they provided might serve as a foundation for an article that is liable to be detrimental to their interests, and is likely to be published by a group that has already made known public findings and issued claims that are vigorously opposed by other victims and by medical investigators who do not accept the methodology or the conclusions of that research group.

With respect to the privacy of patients, it may also be questioned whether the no-fault insurer was morally entitled to undertake a massive invasion of the personal and medical information of everyone on whom it cared to gather data, particularly because it seemed that they intended to gather all such data on nearly everyone making a claim within a particular time-period. Insurers are certainly entitled to acquire information on the basis of a signature from their insured persons, but individuals should not to be asked to provide much of that information unless it is relevant. For example, unless a person is making a complaint of sexual dysfunction, it is usually unreasonable for an insurer to seek information from the person's gynecologist or dermatologist about an injury to a knee. In general, in a tort system, medical information is ultimately available, to a great extent, from the moment that a psychiatric issue is raised, because this provides insurers with an opportunity to ask about almost any aspect of a person's life. Nevertheless, even if such a wide ranging survey is justifiable on occasion, it should only be sought or undertaken if a case is strongly contested. In the many cases where settlement can reasonably be achieved without extensive enquiries, insurers may be pleased to escape the expense of collecting additional medical data, and privacy should be preserved. However, in Saskatchewan, it appears that an insurance company deliberately collected, or was free to collect, extensive amounts of data from different sources, including the provincial health plan, the local workers compensation system, pharmacy prescription records, driving records, Social Services records, etc. This information, collected on large groups of people, was then to be made available to the university to study. Consent was said not to be needed, as Terry shows, because the insurer claimed to be entitled to collect information of all sorts. However, that entitlement should not have been used indiscriminately, and it is plausible to suppose that the insurer was at fault in taking far more information than was necessary for therapeutic purposes, or to achieve valid documentation of the reasons for the insurer's financial commitment and obligations. 
What remedies should be sought for these actions? In our opinion, the University of Saskatchewan has an important obligation to investigate the matter further and to make known the full extent of the role played by the insurance company that funded this research. As well, we consider (3) that The New England Journal of Medicine has an undischarged obligation to further review the scientific basis and the actual implementation of the research from Saskatchewan that it published (2).

\section{REFERENCES}

1. Merskey H, Teasell, RW. The disparagement of pain: Social influences on medical thinking. Pain Res Manag 2001;5:259-70.

2. Cassidy JD, Carroll L, Coté P, Lemstra M, Berglund A, Nygren A. effect of eliminating compensation for pain and suffering on the outcome of insurance claims for whiplash injury. N Engl J Med 2001;342:1179-86.

3. Merskey H, Teasell R, Nussbaum D. Science, whiplash insurance and minimizing pain. The Verdict 2001;90:46-9; The Saskatchewan Advocate 2001;3:19-23; The Litigator 2002:39-43.

The views expressed in this editorial are those of the authors and are not intended to reflect the opinions of the Canadian Pain Society or Pulsus Group Inc

\section{ANNOUNCEMENT}

\section{NOTICE TO THOSE WHO SUBMITTED ABSTRACTS TO \\ THE 2002 ANNUAL CONFERENCE OF THE CANADIAN PAIN SOCIETY \\ "BACK TO THE FUTURE: EMERGING IDEAS ON PAIN MECHANISMS AND TREATMENT" MAY 23-25, 2002, WINNIPEG, MANITOBA}

Abstracts from the 2002 Annual Conference of the Canadian Pain Society, "Back to the Future: Emerging Ideas on Pain Mechanisms and Treatment", have been published in a supplement to the Summer 2002 issue of Pain Research $\mathcal{E}$ Management. It has come to our attention that some contributors' names were not provided, and were, therefore, not included in the publication.

If you have contributed to an abstract from the 2002 Annual Conference, published in Pain Research $\mathbb{E}$ Management, Volume 7, Supplement A, and are aware of any such omissions, please contact Dr Harold Merskey, Editor-in-Chief, by Friday, August 16, 2002. An erratum will be published in a future issue of Pain Research $\mathcal{E}$ Management.

\section{Dr Harold Merskey \\ Editor-in-Chief}

1001 Adelaide Street North, Suite 205

London, Ontario N5Y 2M6

E-mail: merskey@on.aibn.com

Fax: 519-434-8880 


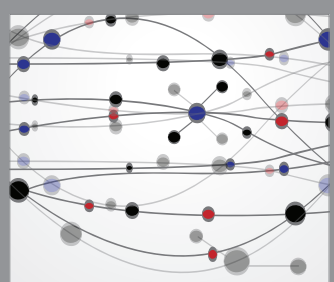

The Scientific World Journal
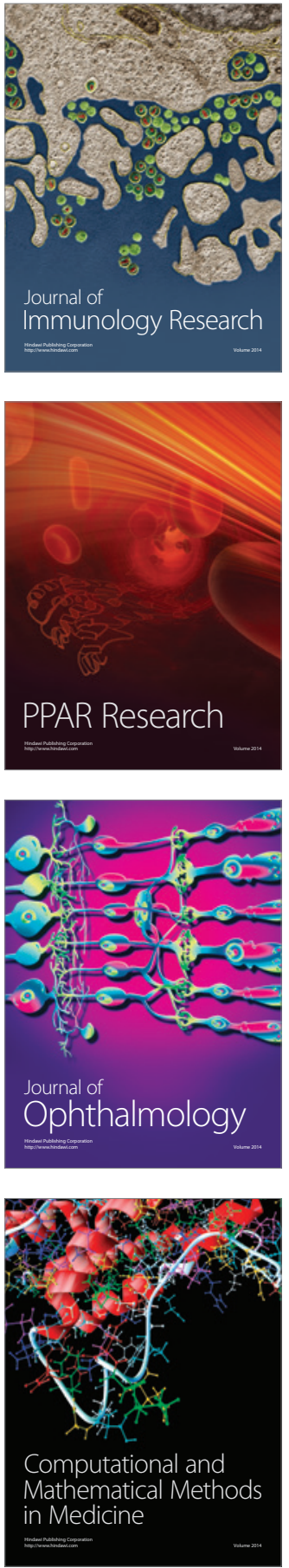

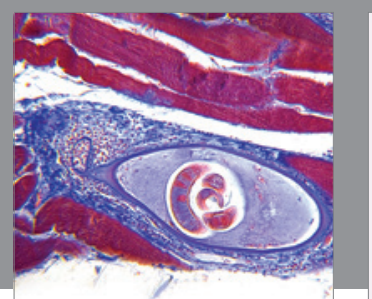

Gastroenterology Research and Practice

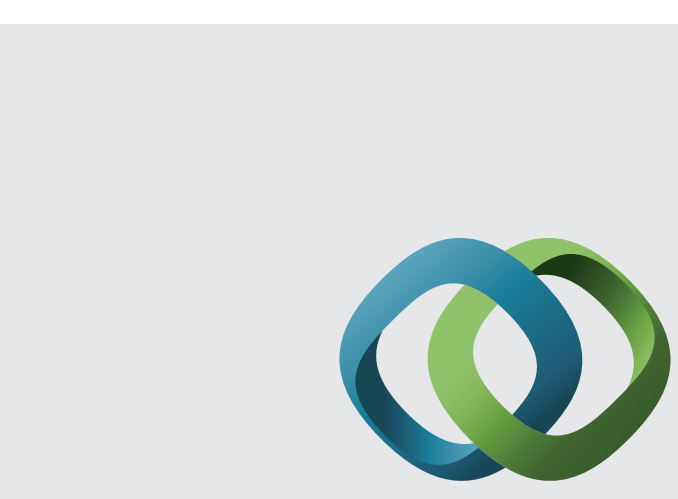

\section{Hindawi}

Submit your manuscripts at

http://www.hindawi.com
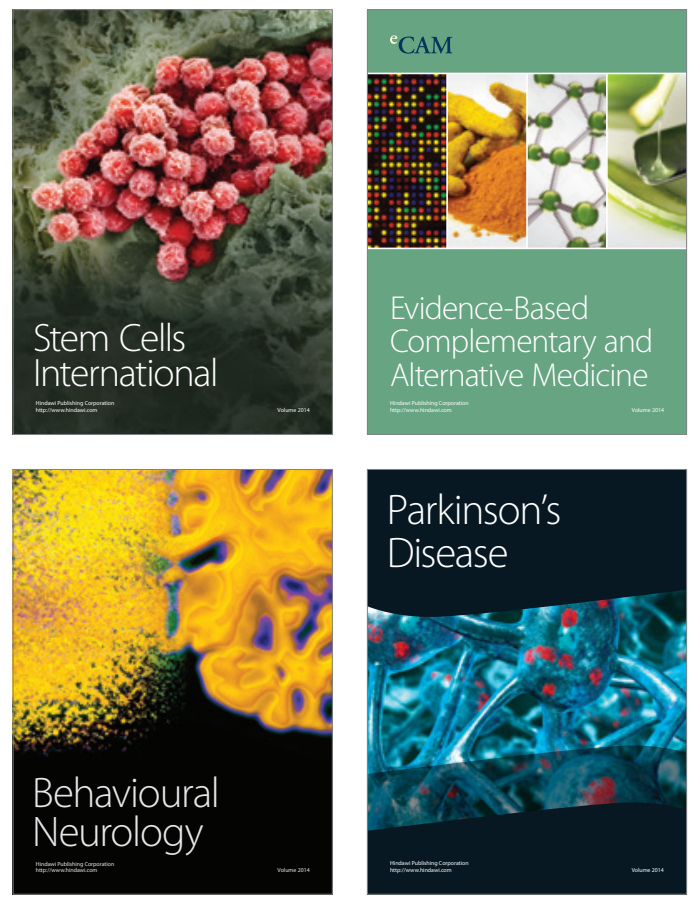
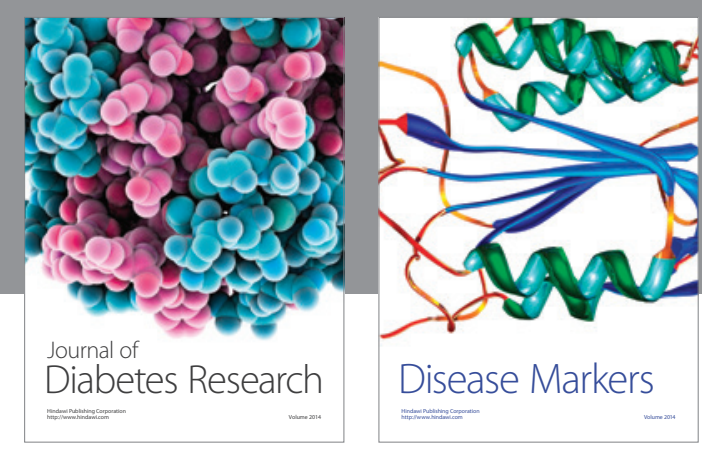

Disease Markers
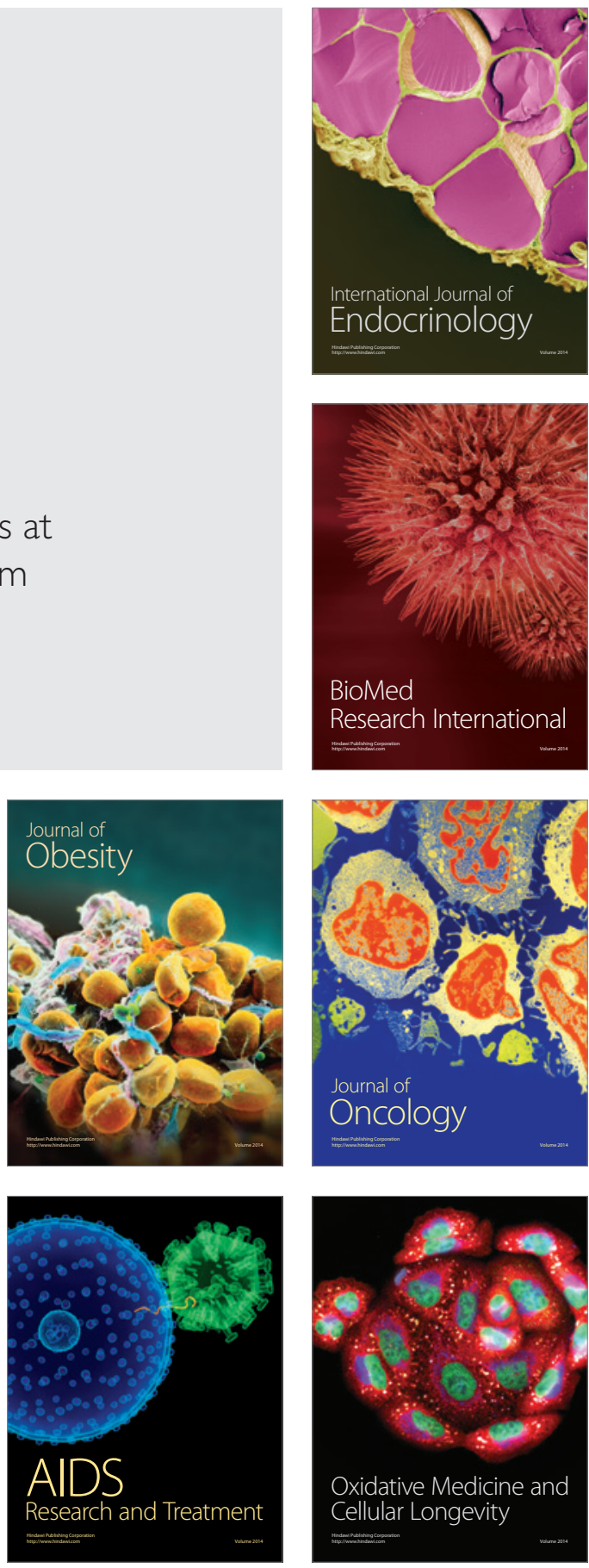